\title{
Assessing Vulnerability of Food Availability to Climate Change in Hai District, Kilimanjaro Region, Tanzania
}

\author{
Anza A. Lema' ${ }^{1}$ Linus K. Munishi2 ${ }^{*}$, Patrick A. Ndakidemi² \\ ${ }^{1}$ Evangelical Lutheran Church in Tanzania, Arusha, Tanzania \\ ${ }^{2}$ School of Life Sciences and Bio-Engineering, Nelson Mandela-African Institution of Science and Technology, \\ Arusha, Tanzania \\ Email: Imkasian@gmail.com
}

Received 11 June 2014; revised 8 July 2014; accepted 3 August 2014

Copyright (C) 2014 by authors and Scientific Research Publishing Inc.

This work is licensed under the Creative Commons Attribution International License (CC BY). http://creativecommons.org/licenses/by/4.0/

(c) (i) Open Access

\section{Abstract}

Climate change has a large effect on agriculture sector and, consequently, on the food available for residents of Hai District and other regions of Tanzania. Based on four decades of climate data, this study assessed the impacts of climate change and its potential vulnerability on food availability in Hai District, Kilimanjaro region. The results from this study suggest an association between food crop production and variation in climate (temperature and rainfall) in Hai District. Considering the aspect of rainfall and temperature, we demonstrate that rainfall and temperature have significant relationship with maize and bean outputs. The rainfall had a strong positive association with maize and beans production and whereas temperature had inverse relationship with maize and beans yields. With the annual loss $\$ 0.04$ million and $\$ 0.01$ million per year from cattle and goats/sheep respectively and the additional annual loss of \$29 million and \$10.8 million from maize and bean crops respectively in Hai District during years of severe and prolonged droughts, our study highlighted how severe droughts can dramatically affect agriculture production and food security in the area. To mitigate climate change and provide effective adaptation measures, it is imperative to develop a broader research framework, which integrates bio-physical and socioeconomic aspects of food systems which addresses its vulnerability and thereby improve food security.

\section{Keywords}

Climate, Food Availability, Rainfall, Temperature, Hai District, Kilimanjaro Region

\footnotetext{
${ }^{*}$ Corresponding author.

How to cite this paper: Lema, A.A., Munishi, L.K. and Ndakidemi, P.A. (2014) Assessing Vulnerability of Food Availability to Climate Change in Hai District, Kilimanjaro Region, Tanzania. American Journal of Climate Change, 3, 261-271. 


\section{Introduction}

Climate variation is one of several factors that affect livelihood of people [1]-[3] often resulting in vulnerability to food shortages. Climates around the world are changing very rapidly as warming and frequent drought continues to increase. Many parts of the world (including Tanzania) have experienced the first decade of the $21^{\text {st }}$ century as the warmest decade on record since modern measurements began around 1850, which was also marked by dramatic climate and weather extremes such as long-term droughts [4] [5].

Climate change has become a source of uncertainty and vulnerability of people's livelihood including food availability (production, distribution and exchange). These marked warming and changes in climate around the world provide a context in which to evaluate the likely effects of climate on food availability [2]. For example, in studies of household food security in Southern Africa, overall, climate was one of the 33 drivers of food security [1] [3], which increased livelihood of people to vulnerability risks. Additionally, observed warming has been linked to increased food insecurity in areas currently vulnerable to hunger and undernutrition [6].

Agriculture production in Hai District is the major economic activity that significantly contributes to food availability in Tanzania. The six most widely grown crops in the district are maize, common bean, coffee, banana, paddy (rice) and sunflower. Among the animals domesticated in the district include; cattle, goat, sheep and chicken. Production of these crops accounts for over $46 \%$ of Hai District cropland area and more than $82 \%$ of food production, grown by more than $80 \%$ of the small scale farmers/residents whose primary source of livelihood is agriculture [7] [8]. Maize is now the staple food of the impoverished majority of the Tanzanian population, whereas the small middle class and the tiny upper class consume rice and wheat [9]. The past decade (2000-2010) has witnessed dramatic decline in rainfall weighted with increased temperature in Hai District (Figure 2). For example, when drought afflicted Tanzania in 2005, Tanzanian newspapers and radios reported that large amounts of maize and rice were being imported in 2006 and that this extensive import was a result of crop failures caused by the drought of the previous year [9].

Several studies of climate change, together with other global environmental changes such as changes in water availability, and land cover, etc., have increased concerns about the potential of climate change to impact on food availability, exacerbating food insecurity especially for poor people.

Although those studies have demonstrated how climate change is associated with food availability and livelihood vulnerability globally and regionally, as is already happening in some places, its precise vulnerability effects are not uniform and are difficult to predict [2] [6] [10] [11] providing little insight into the food availability dimension of food security. Also, the gradual increase in drought and human population has decreased food availability not only in arid and drought-prone areas but also in humid or sub-humid zones, leaving its sustainability to be threatened by various human activities [2] [6].

While creating awareness among different stakeholders dealing with food security in these areas becomes important, further detailed study is necessary to provide quantitative information that would support and provide a framework upon which food could be used and managed. Considering the inadequate of this information and understanding of the effect of climate change on food availability, this study therefore aimed to assess the relationship between climate change and food availability Hai District, northern Tanzania.

In order to reduce uncertainties of many climate impacts of food security, current vulnerability to climatic hazards and stresses as well as to prepare for future climate change, the adaptive capacity of the Hai District needs to be strengthened. This requires, among other things, increased evidence on the effects of climate change impacts on the food access, utilization, and stability dimensions in order to achieve a more holistic understanding of food security [6].

Drought can vary in severity: temperature and rainfall projections from Sub-Saharan Africa, showed, for example, that there will be roughly 54\% increase in armed conflict incidence by the year 2030, which is equivalent to an additional 393,000 battle deaths if future wars are as deadly as recent wars [12]. Extended periods of severe droughts have far-reaching, negative impacts on the availability of water resources, food and agricultural security, human health, tourism and biodiversity [2] [4] [6]. Such a drought was experienced by farmers in areas across the Horn of Africa and for example, the 2009, and 2011 drought was, in some places, the worst to hit the region for 60 years [4] [5]. As a consequence normal patterns of temperature and rainfall and farming were disrupted, with production of some (annual) crops going down below the average per unit area production, while some areas experienced total annual harvest loss in Hai District during the years of drought. Annual crops are most sensitive to variations in rainfall and temperature conditions [10] [13]. Most of the affected crops during 
the years of drought among others are maize, beans and coffee [10], so our analyses focused on production patterns among maize (Zea mays L.) and common bean (Phaseolus vulgaris L.).

This study aims to examine production patterns among different crops and livestock as influenced by changes in climate (temperature and rainfall). The specific objectives were: 1) To determine the rainfall and temperature patterns in Hai District in the past 40 years (1972-2012); 2) To determine the major crops grown and their respective proportions as produced in Hai District; 3) To assess the trends in livestock losses (as caused by drought) for the past decade (2000-2010); 4) To assess the impact of rainfall and temperature on crops production in Hai District.

\section{Methods}

\subsection{Study Area}

The study area is Hai District located in northern Tanzania Hai District is in the northern part of Tanzania [(latitude $2^{\circ} 50^{\prime}-3^{\circ} 29^{\prime} \mathrm{S}$ and longitude $\left.30^{\circ} 30^{\prime}-37^{\circ} 10^{\prime} \mathrm{E}\right)$, Figure 1]. Mean annual rainfall is $521 \pm 188 \mathrm{~mm}(\mathrm{n}=40$ years) and the mean annual temperature is $23.3^{\circ} \mathrm{C} \pm 0.66^{\circ} \mathrm{C}$ ([14], Figure 2). The rainfall is bimodal with two rainy seasons namely: Long rainy season which starts in March and ends in June and while the short season rainy is usually between the months of November and December [8] [14]. In 2009, Hai District experienced the most severe drought in a decade, with only $299 \mathrm{~mm}$ amount of rain-fall in only 44 days (with only $92 \mathrm{~mm}$ of rainfall in 13 days of cropping season) of that year (Figure 7). In 2003, Hai District experienced the second most severe drought in a decade, with only $346 \mathrm{~mm}$ of rain falling in only 25 of days (with only $265 \mathrm{~mm}$ amount of rainfall in 17 days of cropping season) that year (Figure 7).

\subsection{Climate and Agriculture Production Data}

The monthly average temperature (minimum and maximum) and rainfall data for the same time period were obtained from the Kilimanjaro International Airport Meteorological Centre. This centre facilitates the gathering of data from the national (and the world's) leading climate data, monitoring and research centres.

Estimates of Hai District crop yields and livestock production data for 2000-2010 were obtained from the District Agriculture and Livestock Office [8]. Seasonal estimates from available land area data were computed for each crop, with (both commercial and smallholder rainfed sector) production estimated by the annual production of crop in the district. The monitoring of the agriculture production in Hai District is an ongoing activity managed by Hai District Council [8]. Prior to the year 2000, Hai and Siha districts were under one administrative (Hai) district council which have now been divided into two (Siha and Hai) districts; because of this, all the analyses of annual crop production used the end of 2000 as a baseline year for Hai District and were adjusted appropriately to include the crops that were being monitored by Hai District Council only at the time. During the

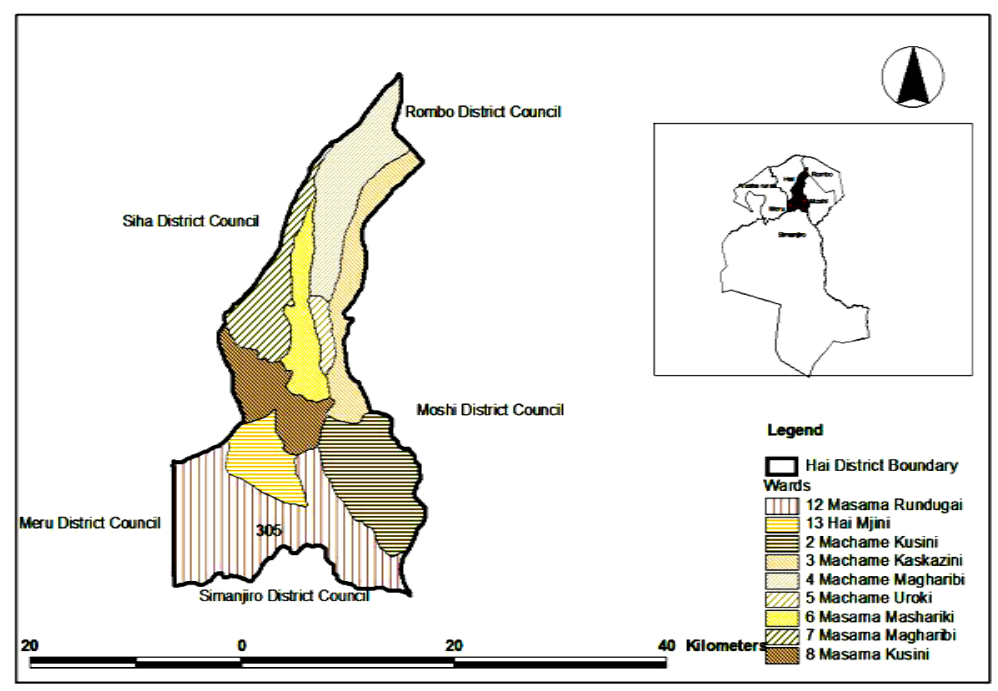

Figure 1. Map of Hai District with administrative boundaries. 
past decade, annual food crop production in Hai District has fluctuated markedly. By the year 2000, Hai District was monitoring its six major crops produced in the area (Table 1).

\subsection{Statistical Analyses}

In order to understand how climate change predicts crop production in Hai District, long-term (40 years) data were used to compare the patterns of rainfall and temperature and annual crop production data collected from the two main food crops: maize and beans. These are the annual crops that are mostly affected by annual variations in temperature and rainfall in Hai and whose productions were recorded for the last decade (Table 1). The long term temperature and rainfall data collected were subjected to statistical analyses for significance levels using correlation analyses in R 2.13.0 (www.r-project.org).

\section{Results}

Figure 2 and Figure 3 show the mean annual temperature and precipitation for Hai District over the past four decades (1972-2012). Using the data for the past decade (2000-2010), the results showed a significant negative correlation between mean annual rainfall and temperature at Hai District over the past eleven years (Pearson's

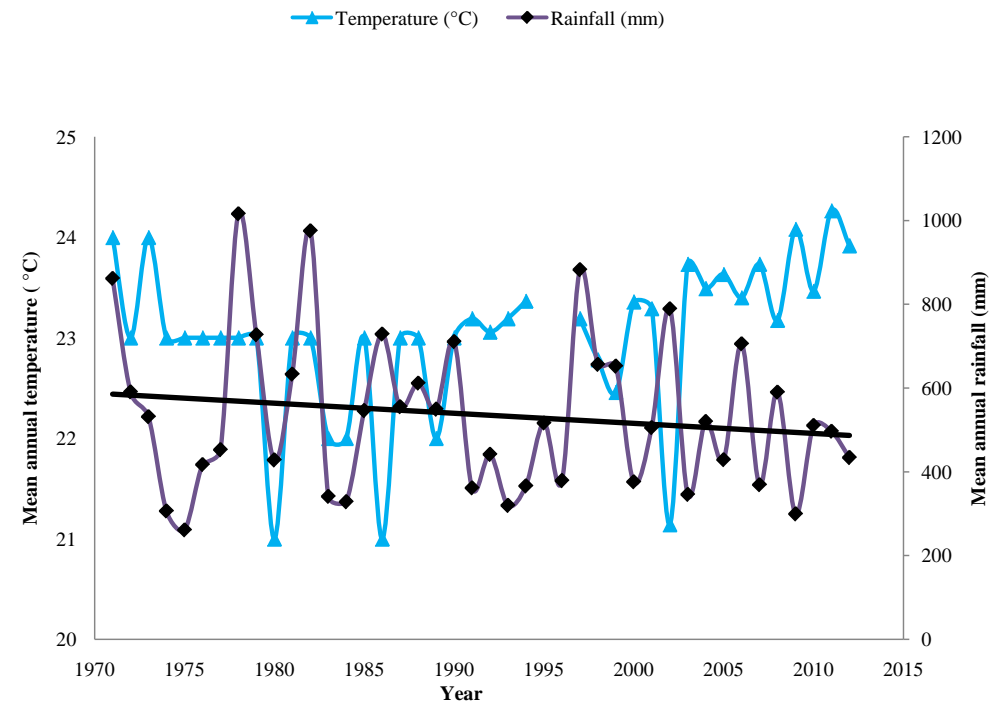

Figure 2. Relationship between mean annual rainfall and temperature in Hai District for the past 40 years.

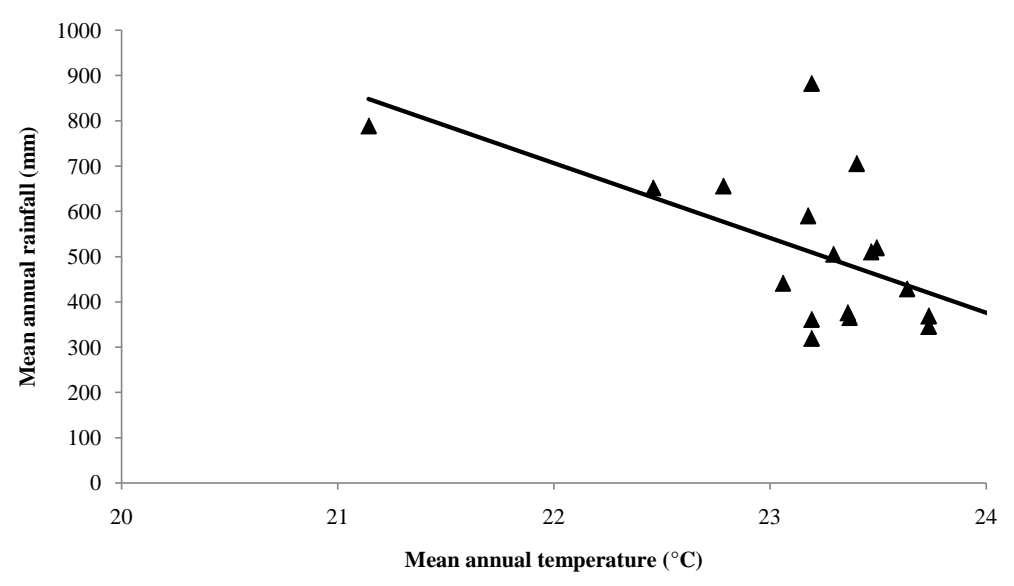

Figure 3. Relationship between mean annual rainfall and temperature in Hai District for the past 11 years. 
correlation, $r=-0.59$, $p$-value $=0.0072$, Figure 3 ).

Agriculture production in Hai District is the major economic activity that significantly contributes to food production and people's income. Based on the result from the household survey, the six most widely grown crops in the district (from highest to lowest production) are maize, common bean, coffee, banana, sunflower and paddy/rice (Figure 4, Table 1). Production of these crops accounts for over $46 \%$ of Hai District cropland area and more than $82 \%$ of food production, grown by more than $80 \%$ of the small scale farmers/residents whose primary source of livelihood is agriculture [7] [8].

Two (2003 and 2009) of 10 years of climate data showed the driest in record over the past decade, recording the lowest maize and beans yields (274 and $39 \mathrm{~kg} \cdot \mathrm{ha}^{-1}$, respectively) in 2003 whereas 100 and $348 \mathrm{~kg} \cdot \mathrm{ha}^{-1}$ of maize and bean respectively were obtained in 2009 (Table 1). Although almost all the crops produced at Hai District were found to be influence by climate change, the most affected ones were maize and bean (Table 1). Temperature and rainfall were strongly correlated with maize and beans production, with rainfall having strong positive association with maize and beans production and temperature having inverse relationship with maize and beans yields (Figure 5 and Figure 6, Table 2). The strength of association between maize production verses temperature and rainfall were also found to be significant (Table 2). Using the maize and bean output data (Table 1) and cattle and goat/sheep mortality (Figure 8) for 2003 as a representative year, the annual loss (due to drought) from agriculture production was estimated and summarized in Table 3.

Changes in climate also have direct impact on livestock mortality. Based on the increase in temperature and decrease in precipitation as indicated in Figure 1 and Figure 2, drought is likely to be more intense and frequent in the coming years. Our study found on average, the annual estimated death of livestock per annum in Hai District during the years of drought was 111 and 274 for cattle and goats/sheep respectively (Figure 8). The death of animals could be attributed mainly due to significant reduction in the available forage for livestock.

\section{Discussion}

As indicated in the results, climate change has a large effect on agriculture sector and, consequently, on the food

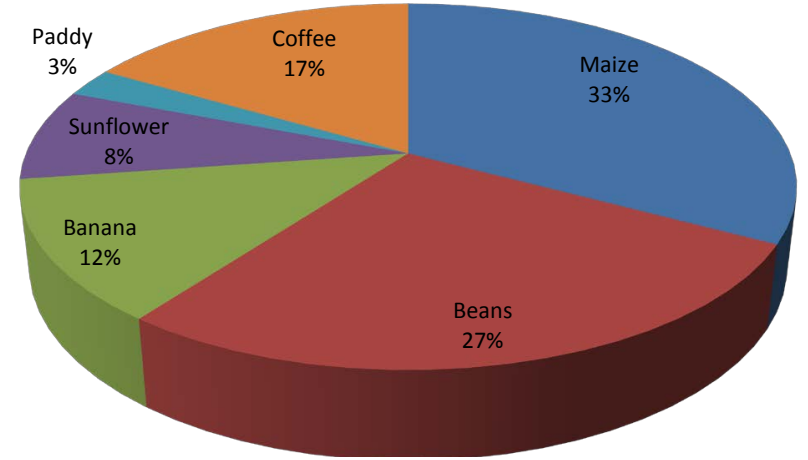

Figure 4. Major crops cultivated in Hai District.

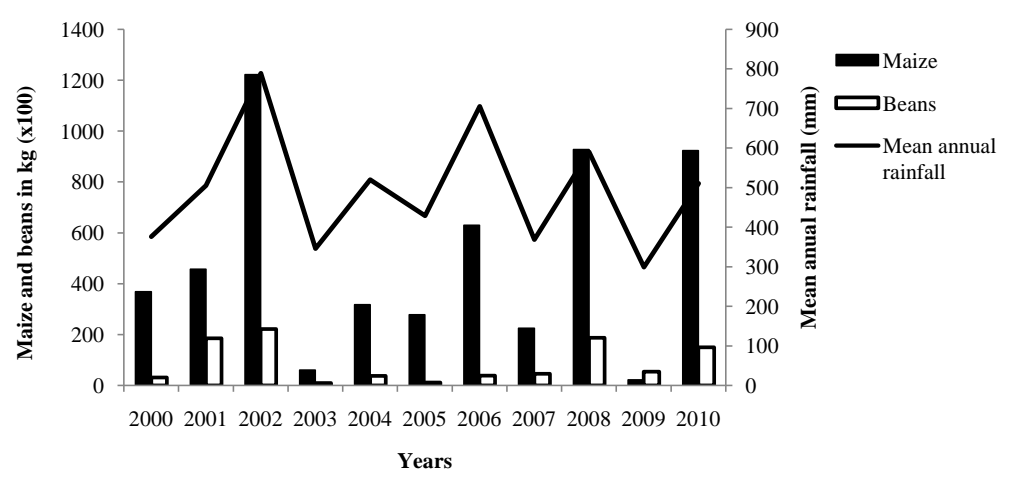

Figure 5. Annual maize and beans output and rainfall patterns in Hai District from 2000 to 2010 . 


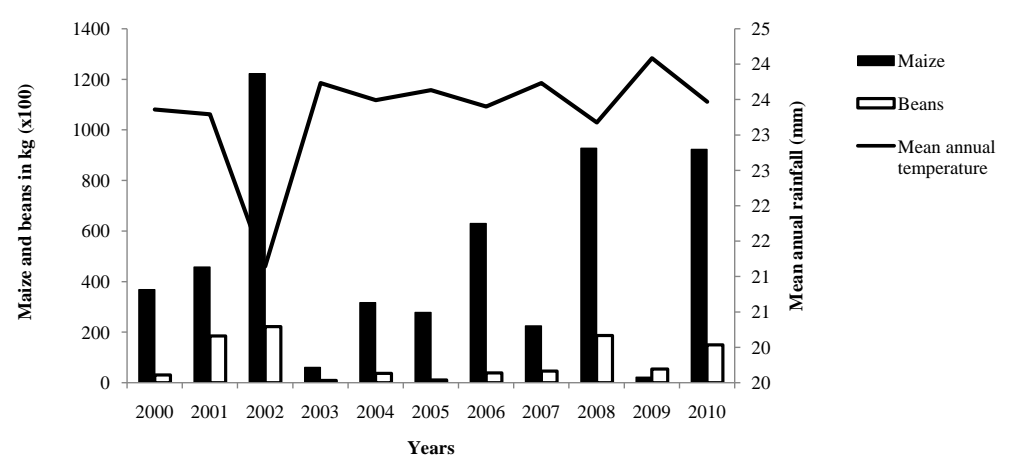

Figure 6. Annual maize and beans output and temperature patterns in Hai District from 2000 to 2010.

Table 1. Annual outputs $\left(\mathrm{kg} \cdot 10^{5}\right)$ estimates for major crops farmed in Hai District for the past ten years.

\begin{tabular}{ccccccccccccc}
\hline Crop/Year & Land Size (ha) & $\mathbf{2 0 0 0}$ & $\mathbf{2 0 0 1}$ & $\mathbf{2 0 0 2}$ & $\mathbf{2 0 0 3}$ & $\mathbf{2 0 0 4}$ & $\mathbf{2 0 0 5}$ & $\mathbf{2 0 0 6}$ & $\mathbf{2 0 0 7}$ & $\mathbf{2 0 0 8}$ & $\mathbf{2 0 0 9}$ & $\mathbf{2 0 1 0}$ \\
\hline Maize & 21,888 & 368 & 457 & 1222 & 60 & 317 & 278.2 & 630 & 225 & 926.6 & 22 & 923 \\
Bean & 15,502 & 312 & 185 & 222 & 6 & 367 & 10.5 & 39.2 & 46.4 & 187 & 54 & 150 \\
Bananas & 16,600 & 2580 & 2580 & 166 & 126 & 750 & 600 & 630 & 1323 & 1350 & 1350 & 1480 \\
Paddy & 4348 & 17.6 & 87.8 & 78.9 & 73.5 & 52.8 & 108 & 123.8 & 125 & 140 & 126 & 142.5 \\
Sunflower & 85 & 2.7 & 1.69 & 3.15 & 3.7 & 4.5 & 8.5 & 6.8 & 6 & 7 & 0.6 & 6.2 \\
Coffee & 12,655 & 8 & 1.7 & 15.3 & 13 & 7.8 & 12.5 & 13 & 15.4 & 26 & 20.6 & 25 \\
\hline
\end{tabular}

Table 2. Correlates of temperature and rainfall with annual maize and beans production at Hai District.

\begin{tabular}{cccc}
\hline Variables (Correlates) & $\mathbf{r}^{2}$ & $\mathbf{p}$-Value & Significance \\
\hline Temperature vs maize yield & -0.78 & 0.00411 & $\mathrm{~S}$ \\
Temperature vs beans yield & -0.68 & 0.0223 & $\mathrm{~S}$ \\
Rainfall vs maize yield & 0.85 & 0.0009 & $\mathrm{~S}$ \\
Rainfall vs beans yield & 0.61 & 0.0474 & $\mathrm{~S}$ \\
\hline
\end{tabular}

$\mathrm{S}=$ significant. Significant values are when $\mathrm{p}<0.05$.

Table 3. Annual estimates of crop and livestock losses in years of drought in Hai District.

\begin{tabular}{|c|c|c|c|}
\hline Livestock & Numbers $\mathbf{y r}^{-1}$ & Unit cost (US \$) & Total loss (US \$) $\mathrm{yr}^{-1}$ \\
\hline Cattle & 111 & 361 & 40,071 \\
\hline Goat/Sheep & 274 & 37 & 10,138 \\
\hline Sub total & 385 & & \\
\hline Crop & Tones $\cdot \mathrm{yr}^{-1}$ & & Total loss (US \$) $\mathrm{yr}^{-1}$ \\
\hline Maize & 116,200 & 250 & $29,050,000$ \\
\hline Beans & 21,600 & 500 & $10,800,000$ \\
\hline Sub total & 137,800 & & \\
\hline Total & & & $39,900,209$ \\
\hline
\end{tabular}


available for residents of Hai District and other parts of the country. The close association between crop (maize and bean) production and temperature and precipitation suggest that there are significant effects of climate change on food availability in Hai District. Higher temperatures eventually reduce yields of desirable crops while encouraging weed and pest proliferation [13]. During the last 120 years, annual precipitation on Mount Kilimanjaro (including Hai District) has decreased by 600 - 1200 mm [15] while since 1972 annual temperature has mostly been on the increase drastically (Figure 2 and Figure 3). Both these climatic changes do not only cause the glaciers on the mountain to retreat [15] but also intensity and frequency of droughts are likely to increase, resulting in a potentially much greater impact on the overall livestock production in the neighborhood of Kilimanjaro ecosystem. We can observe that, on the average, the estimated death of livestock per annum in Hai District during the years of drought was 111 and 274 for cattle and goats/sheep respectively (Table 3, Figure 8). Therefore these data imply that the possible impact on cattle and goats/sheep during the years of drought is equivalent to losses of $\$ 0.04$ million and $\$ 0.01$ million per year respectively (Table 3 ). The death of animals could be attributed mainly due to significant reduction in the available forage for livestock.

Drought is expected to increase in frequency and severity in the future as a result of climate change, mainly as a consequence of not only decreases in regional precipitation but also because of increasing evaporation driven by forest clearing that exacerbates global warming [16]. A study [17] on the slopes of Mount Kilimanjaro indicated that the combined cover of closed and open forests decreased by $68 \%$ while closed and open forests decreased by $56 \%$ and $64 \%$ respectively due to forest clearing and climate change.

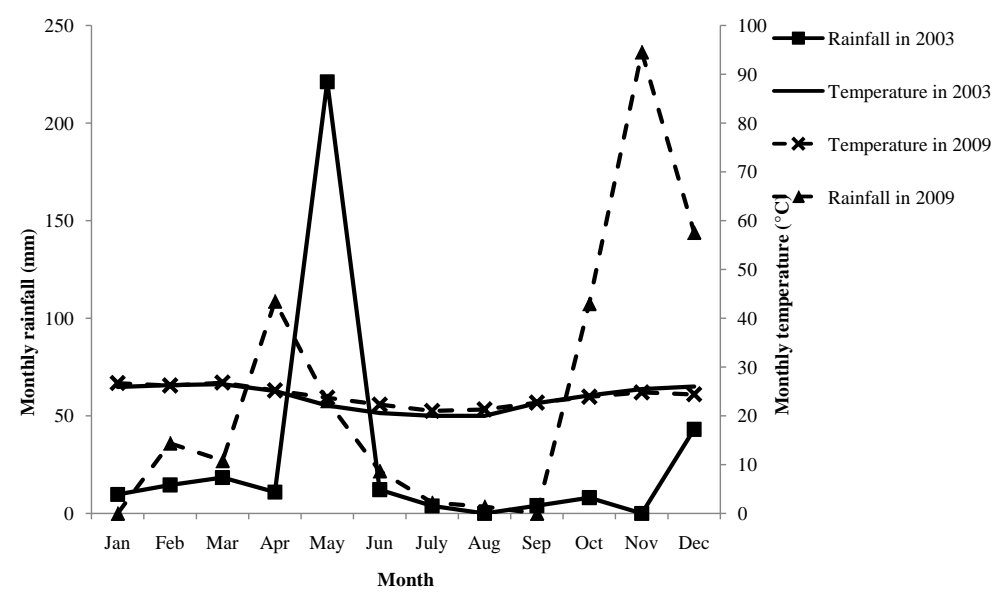

Figure 7. Relationship between monthly rainfall and temperature in Hai District for both 2003 and 2009.

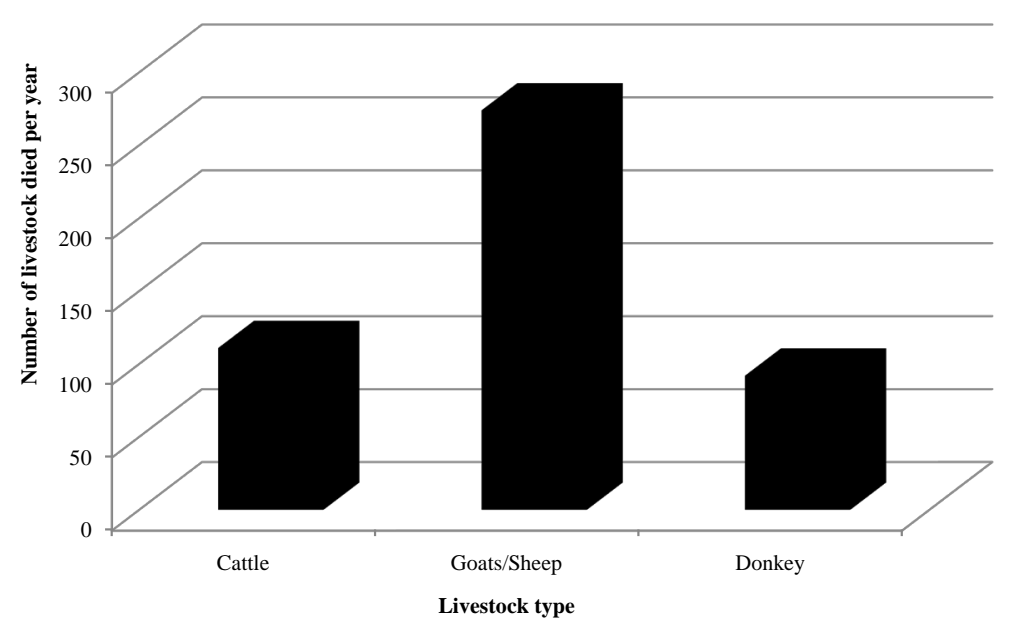

Figure 8. Annual estimates of livestock death during years of drought in Hai District. 
Another study [15] indicated that during the last 70 years, Mount Kilimanjaro has lost nearly one-third of its forest cover, in the upper areas caused by climate-driven fire and clearing. The loss of $150 \mathrm{~km}^{2}$ of cloud forestthe most effective source in the upper montane and subalpine fog interception zone-caused by fire during the last three decades means a considerable reduction in cloud forests and water yield [15].

The cloud forests are of great importance for watersheds in East Africa [15] [18]. In addition to the function of filtering and storing water, the upper montane and subalpine cloud forests have a high potential of collecting cloud water. Fog interception increases with altitude, and so does its contribution to water yielding on higher altitudes of Kilimanjaro [19]. Thus, the loss of cloud forests due to climate induced fires as well as the loss of montane forest due to clearing, causes a considerable reduction and enhanced variability of water yields of the Kilimanjaro catchments.

Agricultural activities in the Hai District depend on rainfall and irrigation and since precipitation decreases from the lower forest boundary of the mountains down to the plains, then most of the areas just few kilometers from the lower elevations are semi-arid in nature requiring irrigation for agriculture production. Irrigation activities have also started to be practiced in highlands, through traditional furrows (mifongo), and this is due to increased drought that comes even before most of the food crops mature [17].

Variation in yields on annual food crop production during the non-drought years in Hai District is generally extremely low, with maize crop having the highest production when compared with other crops. However, in 2003 and 2009, for example almost more than 98 per cent of the maize produced per year did not attain maturity and consequently could not be harvested within that year (Table 1, Figure 5 and Figure 6). The rainfall observed in 2005 and 2007 were not substantially higher than those of 2003 and 2009 compared to their correspondent difference in grain yields. The most possible reason could not be attributed only to low rainfall, and high temperature but more importantly poor rainfall distribution recorded over the entire monitoring period in the district.

Thirteen days of light rainfall (of $92 \mathrm{~mm}$ ) during the cropping season in 2009 (Figure 7) was grossly inadequate to sustain annual crop particularly maize and bean to maturity. On the average, $7.08 \mathrm{~mm}$ of rain in 13 days scattered across the cropping season will not be sufficient to meet the transpiration requirement of annual crop. The remaining amount of rainfall $(299 \mathrm{~mm})$ fell during the short season when the crops are usually not cultivated (Figure 7). However, 2003 had different scenario compared to 2009. Seventeen days of heavy rainfall (265 mm) concentrated majorly in one month of the cropping season (Figure 7) may also be regarded as poor distribution to efficiently support the performance of crop.

As expected for most annual crop varieties [13] [20], annual food crops in Hai District suffered most from the severe drought. In accordance with previous work on effects of climate change on crop production, maize production was moreover lower among other annual food crops than between perennial crops [7] [20]. Estimates of the effects of climate change on maize yields are available from model runs of the Crop Environment Resource Synthesis model (CERES-Maize) [20]. In general, simulation results show that maize yields were lower, as result of higher temperatures and, where applicable, decreased rainfall. The average yield of maize decrease over the entire country was $33 \%$, but simulations produced decreases as high as $84 \%$ in the extremely dry regions of Tanzania [20] [21].

In this study, we also report a strong and significant association between climate change and high variability in the yield patterns of maize over the years in Hai District. These observed reductions in maize yield are mainly due to increases in temperature and to decreases in rainfall amount and distribution during the growing season (Figure 5 and Figure 7) that affects development of the crops and their attainment to maturity. The inferred temperature sensitivities were negative for both maize and bean crops (Table 2), in agreement with several previous assessments [20]-[24]. All instances of significant yield effects were attributable mainly to precipitation trends, as rainfall trends had significant positive associations on yields for both maize and bean. Mechanisms likely responsible for the observed negative relationships include decreases in crop development rates, due to increases in water stress and canopy respiration with warmer temperatures [22].

The agricultural sector is the leading sector of the economy of Tanzania and accounts for over half of the gross domestic product (GDP) and export earnings [20] [25]. The livelihood of more than 80\% of the population that lives in rural areas depends on agriculture [7] [25]. The performance of agriculture is therefore a major factor in determining livelihood fortunes. Given the importance of agriculture for gross domestic product (GDP), employment, and livelihoods in many developing countries, the impacts of climate change on food availability are likely to reverberate throughout the economies of these countries including Tanzania. 
Estimates of lost production (based on the potentially available area) in Hai District due to climate change from this study are 116,200 tones $\cdot \mathrm{yr}^{-1}$ for maize and 21,600 tones $\cdot \mathrm{yr}^{-1}$ for bean, which translates to annual district losses of almost \$29 million and \$10.8 million, respectively (Table 3), using 2012 producer prices in Tanzania. Although the results indicate an overall reduction of more than $98 \%$ in maize production to, equivalent to losses of \$29 million per year, the aggregate results hide enormous severe consequences for agriculture, food supply, economy and employment particularly in years where substantial extreme droughts are experience. For example, whenever the rains fail in Tanzania, it is agriculture and energy (hydroelectric power) sectors that suffer most. Likewise, it can be anticipated that food access and utilization will be affected indirectly via collateral effects on household and individual incomes [6].

The evidence from this study supports the need for considerable investment in adaptation and mitigation actions toward a climate-smart food system that is more resilient to climate change influences on food security.

These unprecedented climate extremes should be a wake-up call for all stakeholders and their impacts urgently need to better address the food security concerns that are central to economic and sustainable development agendas. It is also desirable to develop a broader research framework, which integrates bio-physical and socio-economic aspects of food systems, and thereby address the vulnerability of the food systems and thereby improve food security [2].

Our study illustrates the strong impact of climatic variability on annual food crop and livestock production and the decline in the years of drought is indicative of entrenched vulnerability resulting from a climate impact at local level. Some other recent research suggests that while some crops may respond positively to increased atmospheric carbon dioxide concentrations, the associated effects of higher temperatures and altered patterns of precipitation will probably combine to reduce yields [13]. While annual crops could be more impacted by climate change [13], it is likely that perennial crops would be even more susceptible to changes in the climate. Although there will be gains in some crops in some regions of the world, the overall impacts of climate change on agriculture are expected to be negative, threatening global food security [21] [26].

This study thus provides another example of how extreme climatic events such as droughts can strongly affect crop and livestock production. The reduced maize production in Hai District is an example of one end of the spectrum in crop production and climate dynamics: a one site maize production greatly reduced by droughts, whose yield can increase rapidly in the face of availability of enough rainfall and moderate temperature conditions. Knowledge of this variation in maize and beans yield as influenced by climate variability will be important in improving quantitative planning for adaptive and climate change mitigation measures.

Our expanding body of knowledge of how climate affects crop production should help ensure that any measures and/or decisions that are meant to respond to consequences of climate change are based on the best quantitative information available.

\section{Conclusions}

The results from this study suggest an association between food crop production and variation in climate (temperature and rainfall) in Hai District. Considering the aspect of rainfall and temperature, we demonstrate that rainfall and temperature have significant relationship with maize and bean outputs. The rainfall had a strong positive association with maize and beans production and whereas temperature had inverse relationship with maize and beans yields.

With the annual loss $\$ 0.04$ million and $\$ 0.01$ million per year from cattle and goats/sheep respectively and the additional annual loss of \$29 million and \$10.8 million from maize and bean crops respectively (Table 3) in Hai District during years of severe and prolonged droughts, our study highlighted how severe droughts can dramatically affect agriculture production and food security in the area.

To mitigate climate change and provide effective adaptation measures, it is imperative to develop a broader research framework, which integrates bio-physical and socio-economic aspects of food systems, and thereby address the vulnerability of the food systems in order to improve food security.

\section{Acknowledgements}

We thank the staff at Hai District Council and Kilimanjaro International Airport Meteorological station for providing access to data used in this research. We also thank Mr. Adam Mawenya and Alex Lobora for helping with map preparation. 


\section{References}

[1] Scholes, R.J. and Biggs, R. (2004) Ecosystem Services in Southern Africa: A Regional Assessment. Council for Scientific and Industrial Research, Pretoria.

[2] Gregory, P.J., Ingram, J.S.I. and Brklacich, M. (2005) Climate Change and Food Security. Philosophical Transactions of the Royal Society B, 360, 2139-2148. http://dx.doi.org/10.1098/rstb.2005.1745

[3] Misselhorn, A. (2005) What Drives Food Insecurity in Southern Africa? A Meta-Analysis of Household Economy Studies. Global Environmental Change, 15, 33-42. http://dx.doi.org/10.1016/j.gloenvcha.2004.11.003

[4] Oxfam (2012) Food Crisis in the Horn of Africa Progress Report July 2011-July 2012. Oxford OX2 7BY, UK.

[5] World Meteorological Organization (WMO) (2013) The Global Climate 2001-2010. A Decade of Climate Extremes Summary Report. World Meteorological Organization, Geneva.

[6] Wheeler, T. and von Braun, J. (2013) Climate Change Impacts on Global Food Security. Science, 341, 508-513. http://dx.doi.org/10.1126/science.1239402

[7] United Republic of Tanzania (URT) (2001) Agricultural Sector Development Strategy (ASDS). Ministry of Agriculture, Dar-es Salaam.

[8] United Republic of Tanzania (URT) (2012) Hai District Socio-Economic Profile. United Republic of Tanzania, Hai.

[9] Maghimbi, S. (2007) Recent Changes in Crop Patterns in the Kilimanjaro Region of Tanzania: The Decline of Coffee and the Rise of Maize and Rice African Study Monographs. African Study Monographs, Suppl. 35, 73-83.

[10] Aggarwal, P.K., Joshi, P.K., Ingram, J.S.I. and Gupta, R.K. (2004) Adapting Food Systems of the Indo-Gangetic Plains to Global Environmental Change: Key Information Needs to Improve Policy Formulation. Environmental Science Policy, 7, 487-498. http://dx.doi.org/10.1016/j.envsci.2004.07.006

[11] High-Level Panel of Experts on Food Security and Nutrition (HLPE) (2012) Food Security and Climate Change: A Report by the High-Level Panel of Experts on Food Security and Nutrition of the Committee on World Food Security Report No. 3, HLPE, Rome.

[12] Burke, M.B., Miguel, E., Satyanath, S., Dykema, J.A. and Lobell, D.B. (2009) Warming Increases the Risk of Civil War in Africa. Proceedings of the National Academy of Sciences of the United States of America, 106, 20670-20674. http://dx.doi.org/10.1073/pnas.0907998106

[13] Gregory, P.J., Johnson, S.N., Newton, A.C. and Ingram, J.S. (2009) Integrating Pests and Pathogens into the Climate Change/Food Security Debate. Journal of Experimental Botany, 60, 2827-2838. http://dx.doi.org/10.1093/jxb/erp080

[14] United Republic of Tanzania (URT) (2012) Tanzania Meteorological Agency, Kilimanjaro International Airport Station, Kilimanjaro.

[15] Hemp, A. (2009) Climate Change and Its Impact on the Forests of Kilimanjaro. African Journal of Ecology, 47, 3-10. http://dx.doi.org/10.1111/j.1365-2028.2008.01043.x

[16] Sheffield, J., Wood, E.F. and Roderick, M.L. (2012) Little Change in Global Drought over the Past 60 Years. Nature, 491, 435-438. http://dx.doi.org/10.1038/nature11575

[17] Munishi, P.K.T., Hermegast, A.M. and Mbilinyi, B.P. (2009) The Impacts of Changes in Vegetation Cover on Dry Season Flow in the Kikuletwa River, Northern Tanzania. African Journal of Ecology, 47, 84-92. http://dx.doi.org/10.1111/j.1365-2028.2008.01083.x

[18] Hemp, A. (2006) Continuum or Zonation? Altitudinal Gradients in the Forest Vegetation of Mt. Kilimanjaro. Plant Ecology, 184, 27-42. http://dx.doi.org/10.1007/s11258-005-9049-4

[19] Hemp, A. (2005) Climate Change-Driven Forest Fires Marginalizes the Ice Cap Wasting on Kilimanjaro. Global Change Biology, 11, 1013-1023. http://dx.doi.org/10.1111/j.1365-2486.2005.00968.X

[20] Agrawal, S., Moehner, A., Hemp, M., Valst, S., Hitz, J., Smith, H., Meena, S.M., Mwakifwamba, T. and Mwaipopo, O. U. (2003) Development and Climate Change in Tanzania: Focus on Mount Kilimanjaro. OECD, Paris.

[21] Mary, A.L. and Majule, A.E. (2009) Impacts of Climate Change, Variability and Adaptation Strategies on Agriculture in Semi Arid Areas of Tanzania: The Case of Manyoni District in Singida Region, Tanzania. African Journal of Environmental Science and Technology, 3, 206-208.

[22] Lobell, D.B. and Field, C.B. (2007) Global Scale Climate-Crop Yield Relationships and the Impacts of Recent Warming. Environmental Resources Letter, 2, Article ID: 014002.

[23] Schlenker, W. and Roberts, M.J. (2009) Nonlinear Temperature Effects Indicate Severe Damages to US Crop Yields under Climate Change. Proceedings of the National Academy of Sciences of the United States of America, 106, 1559415598. http://dx.doi.org/10.1073/pnas.0906865106

[24] Lobell, D.B. and Gourdji, S.M. (2012) The Influence of Climate Change on Global Crop Productivity. Plant Physiology, 160, 1686-1697. http://dx.doi.org/10.1104/pp.112.208298 
[25] World Bank (2002) Climate Change Series. Agriculture and Rural Development Department, The World Bank Environment Department.

[26] Easterling, W. (2007) Global Food Security under Climate Change. Pennsylvania State University, University Park. 
Scientific Research Publishing (SCIRP) is one of the largest Open Access journal publishers. It is currently publishing more than 200 open access, online, peer-reviewed journals covering a wide range of academic disciplines. SCIRP serves the worldwide academic communities and contributes to the progress and application of science with its publication.

Other selected journals from SCIRP are listed as below. Submit your manuscript to us via either submit@scirp.org or Online Submission Portal.
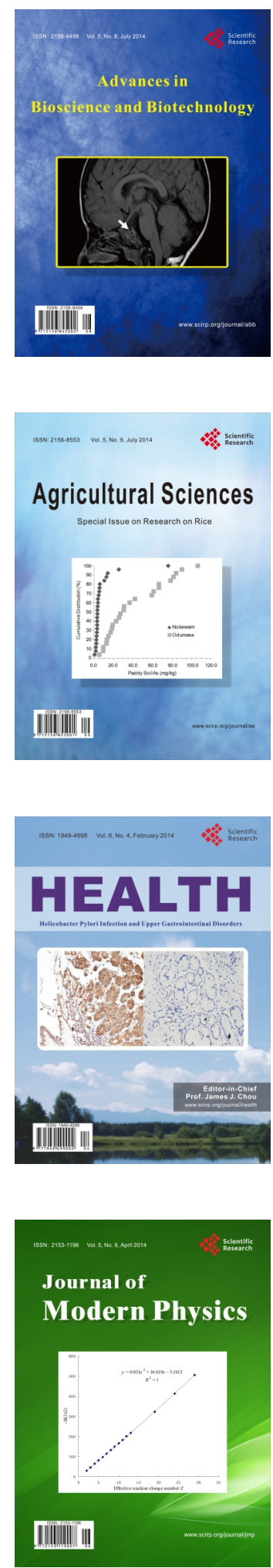
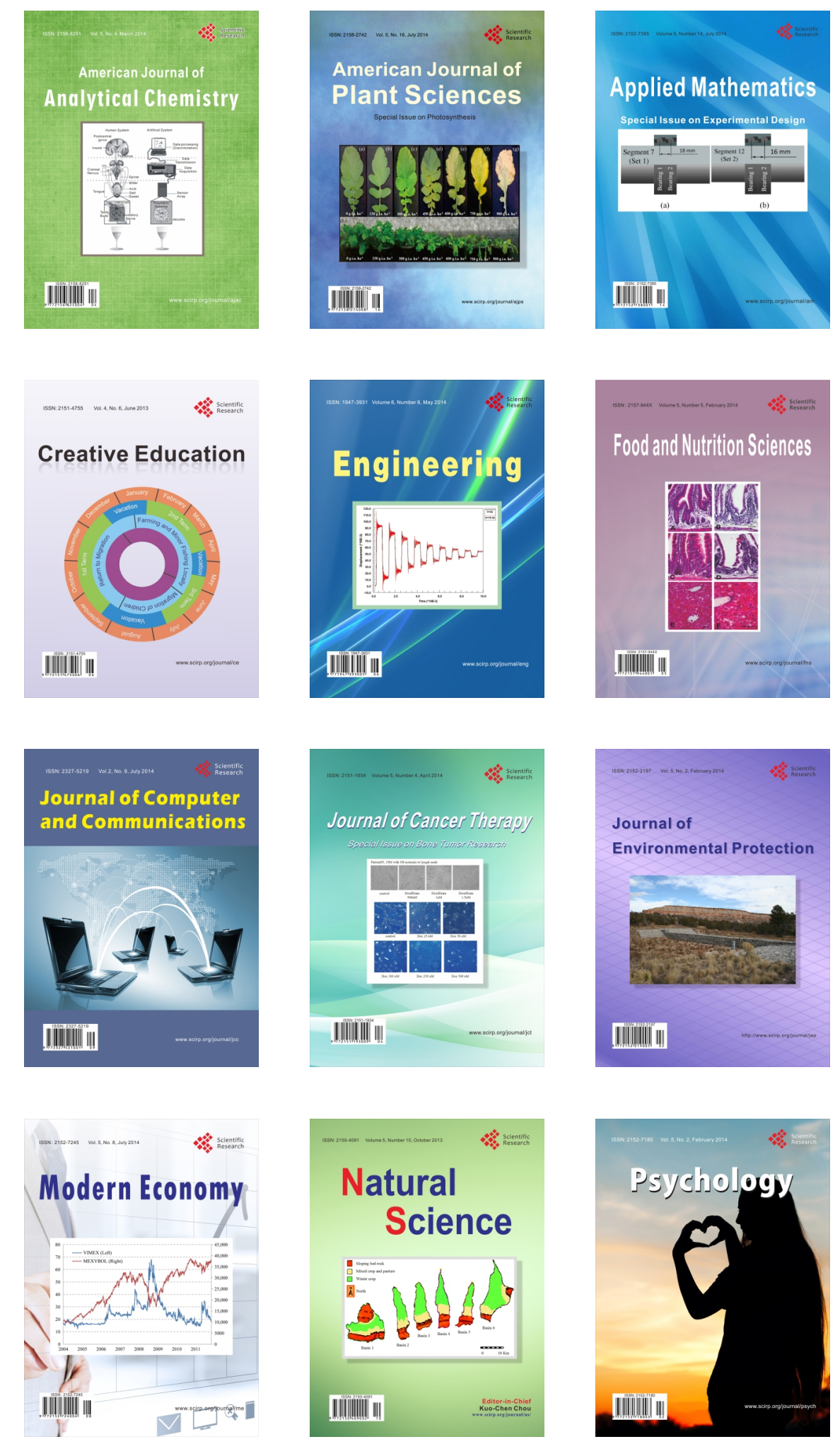